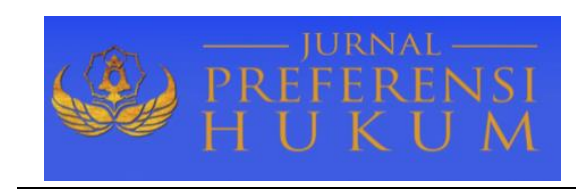

Jurnal Preferensi Hukum | ISSN: XXXX | E-ISSN: XXXX

Vol. 1, No. 2 - September 2020, Hal. 16-20| Available Online at https://www.ejournal.warmadewa.ac.id/index.php/juprehum

DOI: http://doi.org/10.22225/jph.v1i2.2391.16-20

\title{
PENGANGKATAN ANAK OLEH ORANG TUA YANG BERBEDA KEYAKINAN DENGAN CALON ANAK ANGKATNYA
}

\author{
Fransiska Maryl Agatha, I Ketut Widia, I Ketut Sukadana \\ Fakultas Ilmu Hukum Universitas Warmadewa, Denpasar - Bali, Indonesia
}

\begin{abstract}
Abstrak
Pengangkatan anak adalah tindakan hukum untuk mengalihkan hak asuh anak dari orang tua, wali sah atau orang lain yang bertanggung jawab atas kewenangan pengasuhan, pendidikan dan pengasuhan anak ke dalam pengasuhan orang tua angkat. Adopsi Anak pada umumnya banyak dilakukan oleh pasangan suami istri yang tidak dapat memiliki keturunan. Selain faktor reproduksi, masih banyak hal lain yang menjadi motivasi dalam mengadopsi anak, salah satunya adalah belas kasihan. Penelitian ini bertujuan untuk mengkaji tentang persyaratan pengangkatan anak berdasarkan PP No. 54 Tahun 2007 dan akibat hukum pengangkatan anak oleh orang tua angkat yang berbeda keyakinan dengan calon anak angkatnya. Penelitian ini merupakan penelitian hukum normatif. Berdasarkan hasil dan pembahasan penelitian ini, ditemukan bahwa Persyaratan pengangkatan anak berdasarkan PP No. 54 Tahun 2007 sudah diatur dengan jelas, dan tata cara dan persyaratan pengangkatan anak secara terperinci telah diatur dalam Undang-Undang No. 35 Tahun 2014 tentang Perlindungan Anak dengan peraturan pelaksana berupa Peraturan Pemerintah No. 54 Tahun 2007 tentang Pelaksanaan Pengangkatan Anak dan dijelaskan secara lebih rinci dalam Peraturan Menteri Sosial No. 110 Tahun 2009 tentang Persyaratan Pengangkatan Anak. Selain itu, pengangkatan anak oleh calon orang tua yang berbeda keyakinan dapat dilaksakan apabila telah memiliki surat pernyataan dari orang tua kandung calon anak angkat yang menyatakan mengizinkan sang anak mengikuti keyakinan orang tua angkatnya. Sedangkan bagi anak telantar surat penyataan dari orang tua kandung dibuat oleh yayasan atau lembaga yang menampung anak tersebut.
\end{abstract}

Kata kunci: Anak Angkat; Beda Keyakinan; Pengangkatan Anak

\begin{abstract}
Adoption is a legal action to transfer custody of a child from a parent, legal guardian, or another person responsible for the care, education, and care of the child to the care of the adoptive parent. The adoption of children is generally carried out by married couples who cannot have children. Apart from a reproduction factor, there are a lot of other things encouraging adopting a child, one of them is compassion. This study aimed to examine the requirements for adoption based on PP. 54 of 2007 and the legal consequences of adopting children by adoptive parents of different beliefs from the prospective adopted children. This research is a normative legal research. Based on the results and discussion of this study, it was found that requirements for adoption based on PP. 54 of 2007 has been clearly regulated, and the detailed procedures and requirements for adoption have been regulated in Law No. 35 of 2014 concerning Child Protection with implementing regulations in the form of Government Regulation No. 54 of 2007 concerning the Implementation of Adoption and clear details in the Minister of Social Affairs Regulation No. 110 of 2009 concerning Requirements for Adoption of Children. In addition, adoption by prospective parents with different beliefs can be carried out by having a statement letter from the biological parents of the prospective adopted child stating that the child follows the beliefs of the adoptive parents. Whereas for homeless children a statement letter from the biological parents is made by the foundation or institution that accommodates the child.
\end{abstract}

Keywords: Adopted Children; Different Beliefs; Adoption

\section{PENDAHULUAN}

Manusia merupakan makhluk sosial yang memiliki keinginan untuk menjalin hubungan dengan orang lain dan menyatu dengan lingkungan di sekitarnya. Berinteraksi dengan orang lain tidak terlepas dari kebutuhan pemenuhan kasih sayang dan rasa cinta. Kebutuhan akan kasih sayang dapat diperoleh seseorang dimanapun tempatnya. Kebutuhan kasih sayang terlebih dahulu diperoleh di keluarga. 
Pembentukkan sebuah keluarga diawali dengan perkawinan, sebagai salah satu bentuk pemenuhan kebutuhan manusia berupa kebutuhan biologis yang akan diperoleh dalam kehidupan berumah tangga (Rustina, 2014).

Perkawinan adalah suatu ikatan lahir batin antara laki-laki dan perempuan untuk hidup bersama dalam suatu rumah tangga dengan tujuan memenuhi harapan agar memperoleh keturunan yang sehat jasmani dan rohani (Suardiman, 1998). Dalam tujuan perkawinan yang dijabarkan pada Pasal 1 UU No. 1 Tahun 1974 Tentang Perkawinan terdapat unsur keluarga dimana keluarga yang dikatakan ideal atau sempurna terdiri dari ayah, ibu serta anak. Hal inilah yang menyebabkan berbagai usaha akan dilakukan oleh setiap pasangan suami istri untuk memperoleh keturunan baik melalui teknologi yang paling mutakhir seperti bayi tabung maupun dengan melakukan pengangkatan anak atau dikenal dengan adopsi (Balaati, 2013; Ummah, 2005).

Di Indonesia sendiri pengangkatan anak bukanlah suatu hal yang asing. Pengangkatan anak menurut hukum adat mempunyai tingkatan-tingkatan tertentu. Di Bali pengangkatan anak menjadikan anak angkat menjadi anak sah baik secara fisik maupun secara rohani sebagai anak sendiri. Di daerah lain pengangkatan anak tidak menyebabkan hubungan dengan orang tua kandungnya putus. Dengan demikian pengangkatan anak berdasarkan adat pada umumnya semata-mata ditujukan terutama pada kepentingan kesejahteraan anak baik rohani, jasmani maupun sosial. Demikianlah ketentuan hukum mengenai pengangkatan anak yang berlaku menurut hukum adat secara garis besarnya sesuai dengan daerah hukum adatnya masing-masing (Harwati, 2018; Maharani \& Suseno, 2018).

Banyak tujuan lain di balik dilakukannya pengangkatan anak, seperti belas kasihan kepada anak tersebut disebabkan karena orang tua si anak tidak mampu memberikan nafkah kepadanya (Faradz, 2009; Siregar \& Santoso, 2018; Sondakh, 2016). Belas kasihan disebabkan oleh anak yang bersangkutan tidak mempunyai orang tua atau sebagai anak pemancing bagi yang tidak mempunyai anak untuk dapat mempunyai anak. Beberapa waktu yang lalu sempat beredar kabar seorang polisi wanita di Kota Binjai, Sumatera Utara diketahui gagal melakukan adopsi anak dikarenakan beragama minoritas. Padahal anak yang akan diadopsi tersebut merupakan bayi yang ditemukannya di parit dalam kardus. Pengangkatan anak yang hendak dilakukan oleh Polwan tersebut tidak dapat terlaksana berkaitan pada Pasal 3 ayat 1 PP No. 54 Tahun 2007 yang menyebutkan bahwa calon orang tua angkat harus seagama dengan agama yang dianut oleh calon anak angkat.

Dari latar belakang tersebut maka penelitian ini dilakukan dengan tujuan mengkaji persyaratan pengangkatan anak berdasarkan PP No. 54 Tahun 2007 dan akibat hukum pengangkatan anak oleh orang tua angkat yang berbeda keyakinan dengan calon anak angkatnya.

\section{METODE PENELITIAN}

Berdasarkan permasalahan yang dirumuskan penelitian ini didesain dengan menggunakan metode penelitian hukum normatif. Penelitian hukum normatif dilakukan dengan menelaah hukum tertulis dari berbagai pandangan. Pendekatan yang digunakan adalah pendekatan perundang-undangan dan pendekatan konseptual. Sumber data penelitian berasal dari bahan-bahan hukum sekunder dan tersier berupa peraturan perundang-undangan yang mempunyai kekuatan yang mengikat secara umum dan bahan hukum sekunder sebagai penunjang dalam bentuk hasil wawancara dengan beberapa informan. Bahan hukum yang telah terkumpul kemudian dianalisis menggunakan metode kualitatif dan disajikan secara deskriptif.

\section{HASIL DAN PEMBAHASAN}

\section{Persyaratan Pengangkatan Anak Berdasarkan PP No. 54 Tahun 2007}

Pengaturan tentang persyaratan pengangkatan anak diatur secara beragam dalam peraturan perundang-undangan di Indonesia. Pengangkatan Anak haruslah bermuara bagi kebahagiaan anak, sehingga di dalam Pasal 39 UU Perlindungan Anak dinyatakan bahwa pengangkatan anak hanya dapat dilakukan untuk kepentingan yang terbaik bagi anak dan dilakukan berdasarkan adat kebiasaan setempat. Faktor ini yang nantinya dipertimbangkan di Pengadilan saat melakukan pengujian bagi calon orang tua angkat yang merupakan kelanjutan sebelum dilakukannya pengangkatan anak dengan tidak memutuskan hubungan darah si anak angkat dengan orang tua kandungnya dan tidak menutupnutupi identitas orang tua kandung yang dimakasudkan agar kedepannya orang tua angkat memberi alasan yang sejujur-jujurnya tentang informasi mengenai orang tua kandung dari anak angkatnya tersebut. 
Pengaturan mengenai tata cara dari adopsi tertera dalam UU No. 23 Tahun 2002 Tentang Perlindungan Anak. Berikut dengan aturan pelaksananya yaitu PP No. 54 Tahun 2007 dan secara lebih mendalam dan terperinci diatur dalam PERMENSOS No. 110 Tahun 2009 tentang Persyaratan Pengangkatan Anak. Dalam PP No. 54 Tentang Pelaksanaan Pengankatan Anak syarat-syarat pengangkatan anak dibagi ke dalam 2 (dua) bagian yaitu syarat calon anak yang akan diangkat dan bagi calon orang tua yang hendak melakukan pengangkatan anak. Syarat bagi calon anak yang akan diangkat diatur di dalam pasal 12 dalam ayat (1) dan (2) dengan persyaratan di ayat (1) sebagai berikut: berusia belum 18 (delapan belas) tahun, merupakan anak terlantar atau ditelantarkan, berada dalam asuhan keluarga atau lembaga pengasuhan anak dan memerlukan perlindungan khusus. Dalam ayat (2) berisi tentang penjelasan persyaratan mengenai usia dari calon anak angkat.

Sedangkan dalam pasal 13 PP No. 54 Tahun 2007 mengatur mengenai persyaratan bagi calon orang tua yang hendak melakukan pengangkatan anak dengan syarat-syaratnya yaitu: sehat secara jasmani dan rohani, berumur paling rendah 30 (tiga puluh) tahun dan paling tinggi 55 (lima puluh lima) tahun, beragama sama dengan agama calon anak angkat, berkelakuan baik dan tidak pernah dihukum karena melakukan tindak kejahatan, berstatus menikah paling singkat 5 (lima) tahun, tidak merupakan pasangan sejenis. Syarat pengangkatan anak juga terdapat di PERMENSOS No. 110 Tahun 2009 tentang Persyaratan Pengangkatan Anak, terdapat di Bab II yang mengatur tentang persyaratan calon anak angkat dan orang tua angkat yang dibagi menjadi 2 (dua) bagian yaitu bagian pertama mengatur tentang persyaratan bagi calon anak angkat dalam bagian kedua diatur persyaratan bagi calon orang tua angkat.

Sebelum memenuhi semua persyaratan yang tercantum dalam PP tersebut calon orang tua angkat harus terlebih dahulu diajukan pengangkatan anak pada Dinas Sosial setempat sebagai salah satu bagian dari prosedur dalam pelaksanaan pengangkatan anak. Setelah memenuhi seluruh persyaratan dan telah melewati uji kelayakan sebagai orang tua angkat dari Dinas Sosial maka untuk mendapat status sah sang anak angkat harus juga melalui penetapan di Pengadilan supaya sang anak angkat memperoleh status dengan berkekuatan hukum.

\section{Akibat Hukum Pengangkatan Anak oleh Orang Tua Angkat yang Berbeda Keyakinan dengan Calon Anak Angkatnya}

Mengenai akibat hukum setelah dilakukannya pengangkatan anak dapat dikatakan sah apabila dilakukan di hadapan pengadilan sebagai tahapan terakhir dari proses dilakukannya pengangkatan anak. Penetapan dari pengangkatan anak ini berupa pernyataan dari Majelis Hakim yang menyatakan bahwa anak yang hendak diangkat tersebut sudah menjadi anak angkat dari orang tua yang mengajukan pengangkatan anak tersebut. Status sah dari pengadilan bagi anak angkat ini sangatlah penting karena putusan dalam pengadilan dianggap sebagai putusan deklaratoir yang memiliki artia putusan yang bersifat menyatakan atau menegaskan suatu keadaan hukum semata-mata. Penetapan pengangkatan anak di hadapan pengadilan ini juga mencakup banyak hal di antaranya mengenai status hukum dari anak angkat tersebut dalam keluarga angkatnya yang memliki kaitan dengan hak waris dari anak angkat baik dari sisi hukum adat maupun dari perspekrif peraturan perundang-undangan.

Akibat hukum dari anak angkat ini baru benar-benar muncul saat telah keluarnya penetapan dari Pengadilan Negeri dan telah dilakukannya pelaporan oleh orang tua angkat kehadapan Dinas Sosial dan orang tua angkat telah melakukan pencatatan anak angkatnya tersebut di catatan sipil. Dengan sahnya pengangkatan anak yang dilakukan maka akibat hukum yang muncul yaitu berupa hak dan kewajiban antara anak dan orang tua angkat.

Sebagai suatu lembaga hukum, pengangkatan anak memiliki kaitan erat dengan hukum kekeluargaan, hukum harta kekayaan dan hukum waris. Fungsi pengangkatan anak pada beberapa dekade belakangan telah mengalami perubahan, pada mulanya pengangkatan anak dilihat hanya suatu cara memiliki keturunan, kemudian pengangkatan anak dipandang sebagai suatu cara untuk membenahi masa depan anak angkat. Berbagai motivasi dapat dijadikan alasan dalam pengangkatan anak. Di samping tidak memiliki keturunan, pengangkatan anak atas dasar belas kasihan juga acap kali dijadikan alasan, terutama terhadap anak-anak terlantar. Adanya persyaratan bahwa orang tua dan anak angkat harus berkeyakinan sama ini tak jarang menyulitkan calon orang tua angkat melaksanakan pengangkatan anak.

Melaui hasil wawancara kepada narasumber atas nama ibu Ida Ayu Ketut Anggraeni yang menjabat sebagai Kepala Bidang Rehabilitasi Sosial dan dengan narasumber kedua ibu Ni Wayan 
Rusmini yang menjabat sebagai Kepala Seksi Rehabilitasi Sosial Anak dan Lansia Dinas Sosial Provinsi Bali, dalam praktiknya tidak semua pengangkatan anak yang hendak dilakukan oleh calon orang tua yang berbeda keyakinan tidak dapat dilaksanakan. Berdasar penuturan dari ibu Dayu, dalam Peraturan Pemerintah No. 54 Tahun 2007 Tentang Pelaksanaan Pengangkatan diatur dalam pasal 3 bahwa calon orang tua angkat harus memiliki agama yang sama dengan calon anak angkatnya, namun aturan ini tidak diberlakukan untuk seluruh pengajuan pengangkatan anak yang dilakukan oleh calon orang tua angkat yang berbeda keyakinan dengan calon anak angkatnya. Kenyataannya, pengajuan pengangkatan anak oleh orang tua yang berbeda keyakinan banyak terjadi berdasarkan dari data yang terdapat di Dinas Sosial Provinsi Bali. Pengangkatan anak oleh calon orang tua yang berbeda keyakinan dengan calon anak angkatnya ini dapat terlaksana karena dalam praktiknya Dinas Sosial diberikan kewenangan untuk mengizinkan pengangkatan anak tersebut sesuai dengan adat kebiasaan masyarakat di Bali.

Sebelum dilaksanakannya pengangkatan anak calon orang tua yang akan melakukan pengangkatan anak namun berbeda keyakinan terlebih dahulu memiliki surat pernyataan dari orang tua kandung si anak bahwa orang tua kandung dari calon anak angkatnya tersebut memberi izin si anak diperbolehkan untuk mengikuti keyakinan orang tua angkatnya. Dalam hal si anak tidak memiliki orang tua atau termasuk anak terlantar, maka surat pernyataan dibuat oleh yayasan yang menampung anak yang bersangkutan (Wawancara dengan Ida Ayu Ketut Anggraeni, tanggal 30 Januari 2018).

Penjelasan dari narasumber ini juga diterangkan dengan contoh kasus yang beberapa waktu lalu ditangani oleh Dinas Sosial Provinsi Bali dimana ada seorang ibu yang berasal dari Banyuwangi, Jawa Timur yang memiliki seorang anak namun ditinggal pergi oleh sang suami. Karena sang ibu merasa tidak sanggup membiayai sang anak seorang diri, ia mencari orang tua angkat untuk sang anak dan akhirnya ada pasangan suami istri dari Bali yang bersedia untuk mengangkat anak tersebut. Setelah terjadi kesepakatan antara ibu dan pasangan suami istri, pasangan suami istri tersebut mengajukan permohonan pengangkatan anak kepada Dinas Sosial Provinsi Bali karena adanya perbedaan keyakinan antara calon orang tua angkat dengan calon anak angkat maka dari Dinas Sosial meminta surat pernyataan dari ibu kandung anak tersebut sebagai syarat supaya pengangkatan anak dapat dilakukan oleh pasangan suami istri tersebut. Akhirnya ibu kandung si anak membuat surat pernyataan memberi izin sang anak mengikuti agama orang tua angkatnya dan proses pengangkatan anak pun dilakukan (Wawancara dengan Ni Wayan Rusmini, S. Sos, tanggal 29 Januari 2018).

Berdasarkan penjelasan narasumber, perbedaan keyakinan antara calon orang tua angkat dan calon anak angkat ini dalam praktiknya bukan menjadi faktor yang sering dijadikan alasan dari Dinas Sosial menolak pengajuan pengangkatan anak melainkan penolakan terjadi berdasarkan faktor-faktor lain, seperti saat dilakukan 'home visit' (inspeksi) calon orang tua angkat kurang mampu. Calon orang tua angkat yang hendak mengangkat anak harus benar-benar memenuhi spesifikasi 'mampu' dari sudut pandang Dinas Sosial dimana calon orang tua angkat secara penuh mampu membiayai pendidikan si calon anak angkat dan memberikan asuransi kesehatan bagi si anak angkat. Di samping dilihat dari kemampuan ekonominya calon orang tua angkat yang memiliki perilaku kurang baik juga akan mendapat penolakan dari Dinas Sosial. Dalam pengangkatan anak yang dilakukan di daerah Bali persetujuan dari keluarga yang biasanya dalam adat Bali disebut keluarga satu 'natah' juga diperlukan. Apabila terdapat keluarga yang tidak setuju atas pengangkatan anak yang dilakukan maka Dinas Sosial bisa melakukan penolakan terhadap pengajuan pengangkatan anak tersebut. Hal ini terjadi karena di Bali berkaitan dengan kedudukan waris si anak nantinya.

Dinas sosial juga memiliki peranan penting dalam pengawasan setelah pengangkatan anak ditetapkan oleh pengadilan. Dinas sosial memiliki wewenang untuk memantau pola asuh dari orang tua angkat sampai anak yang diangkat tersebut mencapai usia 18 tahun. (Wawancara dengan Ida Ayu Ketut Anggraeni, tanggal 30 Januari 2018).

Peranan dari Pengadilan Negeri menjadi sangat penting dalam pengangkatan anak karena penetapan di pengadilan merupakan suatu pertanda bahwa anak yang diangkat tersebut sudah sah secara hukum menjadi anak angkat dari orang tua yang mengangkatnya. Dengan adanya Penetapan Pengadilan juga akan lebih menjamin kepastian hukum terhadap anak yang diangkat tersebut. 


\section{SIMPULAN DAN SARAN}

\section{Simpulan}

Adapun kesimpulan yang dapat dikemukakan berdasarkan hasil dan pembahasan penelitian di atas, yaitu: pertama, syarat-syarat pengangkatan anak dalam Pasal 13 PP No. 54 Tahun 2007 yaitu sang anak belum mencapai 18 (delapan belas) tahun, merupakan anak terlantar atau ditelantarkan, berada dalam asuhan keluarga atau dalam lembaga pengasuhan anak dan syarat bagi calon orang tua angkat diantaranya sehat jasmani dan rohani, beragama sama dengan agama calon anak angkat, berkelakuan baik dan tidak pernah dihukum karena melakukan tindak kejahatan, dalam keadaan mampu ekonomi dan sosial, memperoleh persetujuan anak dan izin tertulis orang tua atau wali anak, memperoleh izin Menteri dan/atau kepala instansi sosial. Tata cara dan persyaratan pengankatan anak secara terperinci telah diatur dalam Undang-Undang No. 35 Tahun 2014 tentang Perlindungan Anak dengan peraturan pelaksana berupa Peraturan Pemerintah Nomor 54 Tahun 2007 tentang Pelaksanaan Pengangkatan Anak dan dijelaskan secara lebih rinci dalam Peraturan Menteri Sosial Nomor 110 Tahun 2009 tentang Persyaratan Pengangkatan Anak. Kedua, berdasarkan hasil wawancara dengan Kepala Bidang Rehabilitasi Sosial di Dinas Sosial Provinsi Bali, pengangkatan anak oleh calon orang tua yang berbeda keyakinan dapat dilaksakan apabila telah memiliki surat pernyataan dari orang tua kandung calon anak angkat yang menyatakan mengizinkan sang anak mengikuti keyakinan orang tua angkatnya. Sedangkan bagi anak telantar surat penyataan dari orang tua kandung dibuat oleh yayasan atau lembaga yang menampung anak tersebut.

\section{Saran}

Ada juga beberapa saran yang perlu disampaikan kepada beberapa pihak, yaitu: pertama, bagi permerintah, perlu diadakan pembaharuan peraturan perundang-undangan yang berkaitan dengan pengangkatan anak ini supaya lebih relevan dengan kenyataan yang terjadi di masyarakat. Sehingga kedepannya pengangkatan anak selain dilakukan demi melindungi kepentingan hukum dan meningkatkan kesejahteraan si anak angkat tapi juga bisa menjadi lebih adil dalam persyaratanpersyaratan yang tertera dalam Undang-Undang bagi calon orang tua angkat. Selanjutnya perlu juga diperhatikan tentang ditentukannya sanksi atau ancaman pidana bagi mereka yang melanggar ketentuan serta syarat-syarat pengangkatan anak. Kedua, untuk masyarakat yang ingin melakukan pengangkatan anak, hendaknya mencari tau secara jelas mengenai persyaratan serta prosedur yang benar dalam melakukan pengangkatan anak, sehingga di kemudian hari tidak menimbulkan dampak hukum yang menyulitkan bagi si anak angkat.

\section{DAFTAR PUSTAKA}

Balaati, D. (2013). Prosedur dan Penetapan Anak Angkat di Indonesia. Lex Privatum, 1(1), 138-145. Faradz, H. (2009). Pengangkatan Anak Menurut Hukum Islam. Jurnal Dinamika Hukum, 9(2), 153159.

Harwati, T. (2018). Pergeseran Orientasi Adopsi Anak di Kalangan PNS. Qawwam, 11(2), 152-187.

Maharani, \& Suseno, I. (2018). Pengangkatan Anak Warga Negara Indonesia oleh Warga Negara Asing. Mimbar Keadilan Jurnal Ilmu Hukum, 127-143.

Rustina. (2014). Keluarga dalam Kajian Sosiologi. Musawa, 6(2), 287-322.

Siregar, Y. T., \& Santoso, M. B. (2018). Peran Pekerja Sosial dalam Adopsi Anak. Kumawula, 1(3), 202-218.

Sondakh, C. V. (2016). Pengangkatan Anak Menurut Sistem Hukum Adat di Kabupaten Minahasa. Lex Privatum, 4(1), 130-138.

Suardiman. (1998). Kehidupan Perkawinan Bahagia: Dampak Positif untuk Keseimbangan Mental Anak Kini dan Nanti. Buletin Psikologi, 6(2), 40-49.

Ummah, K. (2005). Adopsi sebagai Upaya Melindungi Hak-Hak Anak dalam Perspektif Hukum Islam. Jurnal Hukum, 12(29), 76-87. 